\title{
Knowledge Level of Grade XII Senior High School Students Regarding HIV/AIDS
}

\author{
Stanley Lesmana ${ }^{1}$, Riyadh Ikhsan', Azriya Azka \\ ${ }^{1,3}$ Student, Faculty of Medicine, Universitas Sumatera Utara, Medan, Indonesia \\ ${ }^{2}$ Department of Dermatology and Venereology, Universitas Sumatera Utara Hospital
}

\begin{abstract}
Background: AIDS (Acquired Immunodeficiency Syndrome) is a collection of symptoms or diseases caused by a decrease in the immune system from the body due to infection from the HIV (Human Immunodeficiency Virus) which belongs to the retroviridae family. Teenagers themselves are vulnerable to HIV/AIDS. The right and precise knowledge of HIV and AIDS is important in HIV prevention efforts in adolescents. Method: This research is a descriptive research with cross-sectional design. The sample population of this study was grade XII senior high school students of the 2020/2021 at Methodist -2 Medan by sampling total sampling. This study was analyzed univariately to look at the descriptive images. Result: From the results of this study, it has obtained that the knowledge level of students grade XII Methodist - 2 Medan had good knowledge about HIV / AIDS with the number of 144 people (70.6\%). Conclusion: From this study, it was found that the level of knowledge about HIV/AIDS was mostly in a good category.
\end{abstract}

Keyword: AIDS, HIV, Knowledge, Senior High School

\begin{abstract}
Abstrak. AIDS (Acquired Immunodeficiency Syndrome) secara definisi merupakan kumpulan gejala atau penyakit yang disebabkan oleh penurunan sistem kekebalan dari tubuh akibat infeksi dari virus HIV (Human Immunodeficiency Virus) yang termasuk famili retroviridae. Remaja sendiri termasuk populasi yang rentan terkena HIV/AIDS. Pengetahuan yang benar dan tepat tentang HIV dan AIDS penting dalam upaya pencegahan HIV pada remaja. Tujuan: Penelitian ini adalah penelitian deskriptif dengan design cross-sectional. Populasi sampel penelitian ini adalah siswa/i SMA kelas XII tahun ajaran 2020/2021 yang bersekolah di Methodist - 2 Medan dengan cara pengambilan sampel total sampling. Penelitian ini dianalisis secara univariat untuk melihat gambaran deskriptif. Dari hasil penelitian ini diperoleh tingkat pengetahuan siswa/i Kelas XII Methodist - 2 Medan telah memiliki pengetahuan yang baik mengenai HIV/AIDS dengan jumlah 144 orang (70,6\%). Kesimpulan: Dari penelitian ini, ditemukan bahwa tingkat pengetahuan tentang HIV / AIDS sebagian besar dalam kategori yang baik
\end{abstract}

Kata Kunci: AIDS, HIV, pengetahuan, SMA.

Received 30 January 2021 | Revised 27 February 2021 | Accepted 28 February 2021

\footnotetext{
${ }^{*}$ Corresponding author at: Faculty of Medicine, Universitas Sumatera Utara, Jalan Dr. T. Mansur No. 5, Medan 20155, North Sumatera, Indonesia

E-mail address: stanley.lesmana99@gmail.com
} 


\section{Introduction}

AIDS (Acquired Immunodeficiency Syndrome) is a collection of symptoms or diseases caused by a decrease in the immune system from the body due to infection from the HIV (Human Immunodeficiency Virus) virus that belongs to the retroviridae family. HIV/AIDS itself is still a public health problem globally. This was reflected in World Health Organization (WHO) data, in 2018, reported about 37.9 million people with HIV/AIDS, about 770,000 people died from AIDS, and about 1.7 million people were newly infected with HIV [1, 2].

Teenagers themselves were among the populations vulnerable to HIV/AIDS. During adolescence, significant biological, psychological and behavioral development occurs. At this time, adolescents tend to rarely think about sacrifices and long-term consequences. As a result, health decisions, especially sexual health in adolescents, tend to be reactionary rather than preventive, as reflected in the rate of sexually transmitted diseases (including HIV) where the number of HIVinfected adolescents and young adults worldwide keeps increasing. In 2018, 510,000 (approximately 300,000 - 740,000) peoples aged between 10 and 24 years old were infected with HIV, of whom 190,000 (about 59,000-380,000) were teenagers between the age of 10 and 19 [3, 4].

One of the factors that can prevent HIV / AIDS was a good level of knowledge about HIV / AIDS both from the individual himself and from his parents. The right and precise knowledge of HIV and AIDS were one of the key points in efforts to prevent and avoid HIV in adolescents, although good knowledge did not guarantee that adolescents would not carry out activities that were at risk of being infected with HIV. Therefore, one of the efforts to prevent HIV and AIDS in adolescents was increasing adolescent's knowledge about HIV/AIDS [5].

\section{Method}

This research was conducted at Methodist - 2, located at Jalan M.H. Thamrin No.96, Medan City, North Sumatra Province. This location was chosen as a research place because the school was in a big city so it was expected that students there had understood how to fill out online questionnaires. This research is a descriptive research with cross-sectional design. The target population of this research is all Grade XII students at Methodist - 2 Medan school year 2020/2021. Sampling technique used in this study is the total sampling method using online questionnaire that will be distributed to all Grade XII students at Methodist school - 2 and all who fill out the questionnaire will be processed. The questionnaire used was a questionnaire from Asmadi's research [6]. This questionnaire contain 20 question points about HIV/AIDS which validity had been tested with CVI (Content Validity Index) results of 0.9, a valid questionnaire had a CVI result of $>0.75$. The reliability test of this questionnaire was tested using KR-21 with a result of 0.73 . A questionnaire is realiable if the result of $K R>0.70$. 


\section{Results}

In this study, the samples collected using questionnaires were 204 respondents of grade XII high school students at Methodist - 2 Medan school year 2020/2021 who were willing to fill out questionnaires and meet inclusion and exclusion criteria. An overview of respondent's characteristics by gender can be seen in table 1 and a description of respondent's characteristics based on sources used to obtain information about HIV/AIDS can be seen in table 2.

Table 1 , Characteristics of Respondents by Gender

\begin{tabular}{lcc}
\hline \multicolumn{1}{c}{ Gender } & Frequency & Percentage (\%) \\
\hline Male & 74 & 36.3 \\
Female & 130 & 63.7 \\
Total & 204 & 100 \\
\hline
\end{tabular}

Based on table 1 above, shows that there were more female respondents than male. Male respondents were 74 people with a percentage of $36.3 \%$ while female respondents were 130 people with a percentage of $63.7 \%$.

Table 2 Characteristics of Respondents by Source of Information

\begin{tabular}{lcc}
\hline \multicolumn{1}{c}{$\begin{array}{c}\text { Source of } \\
\text { Information }\end{array}$} & Frequency & Percentage (\%) \\
\hline Internet & 112 & 54.9 \\
Family & 12 & 5.9 \\
Health Workers & 6 & 2.9 \\
School & 35 & 17.2 \\
Friend & 27 & 13.2 \\
Television/Radio & 12 & 5.9 \\
Total & 204 & 100 \\
\hline
\end{tabular}

From the data, it can be seen that the majority of respondents received information about HIV / AIDS from the internet with the number of 112 people while at least received source of information from health workers with a total of 6 people. These results were in line with the research conducted by Ratyas [7] in 2018 and Martilova [8] in 2020. In the research that had been conducted by Ratyas at Public High School 2 Sleman, from 59 respondents, it was found that the majority of respondents obtained sources of information about HIV / AIDS from electronic media in the form of the internet by 29 respondents (49.2\%) [7]. In the research that had been conducted by Martilova in 2020 at Public High School 7 Pekanbaru, the majority of respondents received information from non-health workers as many as 46 people (55.4\%) than getting a source of information from the health workers [8]. The level of knowledge about HIV/AIDS in this study was divided into three groups, namely good, sufficient, and less. After data collection and interpretation of knowledge level results by researchers, the results had been summarized in the form of frequency and percentage distribution tables and can be seen in table 3 . The table showing the distribution of frequency and percentage of knowledge level based on gender is shown in table 
4 , based on the source of information in table 5 , based on the father's last education in table 6 , and based on the mother's last education in table 7. The distribution of frequency and percentage of answers to 20 questions answered correctly or incorrectly is summarized in table 8 .

Table 3 Level of Knowledge About HIV/AIDS

\begin{tabular}{lcc}
\hline Level of Knowledge & Frequency & Percentage (\%) \\
\hline Good & 144 & 70.6 \\
Sufficient & 52 & 25.5 \\
Less & 8 & 3.9 \\
Total & 204 & 100 \\
\hline
\end{tabular}

Table 4 Level of Knowledge Based on Gender

\begin{tabular}{|c|c|c|c|c|c|c|c|c|}
\hline \multirow[t]{3}{*}{ Gender } & \multicolumn{8}{|c|}{ Level of Knowledge } \\
\hline & \multicolumn{2}{|c|}{ Good } & \multicolumn{2}{|c|}{ Sufficient } & \multicolumn{2}{|c|}{ Less } & \multicolumn{2}{|c|}{ Total } \\
\hline & $\mathbf{N}$ & $\%$ & $\mathbf{n}$ & $\%$ & $\mathbf{n}$ & $\%$ & $\mathbf{n}$ & $\%$ \\
\hline Male & 58 & 40.3 & 14 & 26.9 & 2 & 25 & 74 & 36.3 \\
\hline Female & 86 & 59.7 & 38 & 73.1 & 6 & 75 & 130 & 63,7 \\
\hline Total & 144 & 100 & 52 & 100 & 8 & 100 & 204 & 100 \\
\hline
\end{tabular}

Table 5 Level of Knowledge Based on Source of Information

\begin{tabular}{|c|c|c|c|c|c|c|c|c|}
\hline \multirow{3}{*}{$\begin{array}{l}\text { Source of } \\
\text { Information }\end{array}$} & \multicolumn{8}{|c|}{ Level of Knowledge } \\
\hline & \multicolumn{2}{|c|}{ Good } & \multicolumn{2}{|c|}{ Sufficient } & \multicolumn{2}{|c|}{ Less } & \multicolumn{2}{|c|}{ Total } \\
\hline & $\mathbf{N}$ & $\%$ & $\mathbf{n}$ & $\%$ & $\mathbf{N}$ & $\%$ & $\mathbf{n}$ & $\%$ \\
\hline Internet & 78 & 54.2 & 29 & 55.8 & 5 & 62.5 & 112 & 54.9 \\
\hline Family & 8 & 5.6 & 3 & 5.8 & 1 & 12.5 & 12 & 5.9 \\
\hline Health Workers & 3 & 2.1 & 3 & 5.8 & 0 & 0 & 6 & 2.9 \\
\hline School & 29 & 20.1 & 5 & 9.6 & 1 & 12.5 & 35 & 17.2 \\
\hline Friend & 20 & 13.9 & 6 & 11.5 & 1 & 12.5 & 27 & 13.2 \\
\hline Television/Radio & 6 & 4.2 & 6 & 11.5 & 0 & 0 & 12 & 5.9 \\
\hline Total & 144 & 100 & 52 & 100 & 8 & 100 & 204 & 100 \\
\hline
\end{tabular}

Based on table 5 above. shows that the majority of respondents with good knowledge gained information about HIV/AIDS from the internet.

Table 6 Level of Knowledge Based on Father's Last Education

\begin{tabular}{lcccccccc}
\hline \multicolumn{1}{c}{$\begin{array}{c}\text { Father's Last } \\
\text { Education }\end{array}$} & \multicolumn{2}{c}{ Good } & \multicolumn{3}{c}{ Level of Knowledge } & \multicolumn{2}{c}{ Sufficient } & \multicolumn{2}{c}{ Less } & \multicolumn{2}{c}{ Total } \\
& $\mathbf{N}$ & $\%$ & $\mathbf{N}$ & $\%$ & $\mathbf{N}$ & $\%$ & $\mathbf{n}$ & $\%$ \\
\hline Doctorate & 0 & 0 & 1 & 1.9 & 0 & 0 & 1 & 0.5 \\
Master & 12 & 8.3 & 1 & 1.9 & 0 & 0 & 13 & 6.4 \\
Bachelor & 65 & 45.1 & 25 & 48.1 & 0 & 0 & 90 & 44.1 \\
High School & 59 & 41 & 25 & 48.1 & 5 & 62.5 & 89 & 43.6 \\
Junior High & 5 & 3.5 & 0 & 0 & 3 & 37.5 & 8 & 3.9 \\
School & 3 & 2.1 & 0 & 0 & 0 & 0 & 3 & 1.5 \\
Elementary & 144 & 100 & 52 & 100 & 8 & 100 & 204 & 100 \\
Total & & & & & & & &
\end{tabular}


Based on table 6 and table 7, it can be seen that in the good knowledge level group, the last education of the majority of respondent's parents were the bachelor education level and the second place was high school education level.

Table 7 Level of Knowledge Based on Mother's Last Education

\begin{tabular}{|c|c|c|c|c|c|c|c|c|}
\hline \multirow{3}{*}{$\begin{array}{l}\text { Mother's Last } \\
\text { Education }\end{array}$} & \multicolumn{8}{|c|}{ Level of Knowledge } \\
\hline & \multicolumn{2}{|c|}{ Good } & \multicolumn{2}{|c|}{ Sufficient } & \multicolumn{2}{|c|}{ Less } & \multicolumn{2}{|c|}{ Total } \\
\hline & $\mathbf{N}$ & $\%$ & $\mathbf{N}$ & $\%$ & $\mathbf{N}$ & $\%$ & $\mathbf{n}$ & $\%$ \\
\hline Doctorate & 0 & 0 & 1 & 1.9 & 0 & 0 & 1 & 0.5 \\
\hline Master & 2 & 1.4 & 2 & 3.8 & 0 & 0 & 4 & 2 \\
\hline Bachelor & 78 & 54.2 & 28 & 53.8 & 0 & 0 & 106 & 52 \\
\hline High School & 58 & 40.3 & 19 & 36.5 & 5 & 62.5 & 82 & 40.2 \\
\hline Junior High School & 5 & 3.5 & 1 & 1.9 & 2 & 25 & 8 & 3.9 \\
\hline Elementary & 1 & 0.7 & 1 & 1.9 & 1 & 12.5 & 3 & 1.5 \\
\hline Total & 144 & 100 & 52 & 100 & 8 & 100 & 204 & 100 \\
\hline
\end{tabular}

Table 8 Distribution of Respondent's Answers by Question Item

\begin{tabular}{|c|c|c|c|c|c|}
\hline \multirow[t]{2}{*}{ No } & \multirow[t]{2}{*}{ Questions } & \multicolumn{4}{|c|}{ Respondent's Answers } \\
\hline & & Correct & $\%$ & Wrong & $\%$ \\
\hline 1 & $\mathrm{HIV}$ is an AIDS-causing virus & 187 & 91.7 & 17 & 8.3 \\
\hline 2 & $\begin{array}{l}\text { Someone who is HIV positive can suffer } \\
\text { from AIDS }\end{array}$ & 186 & 91.2 & 18 & 8.8 \\
\hline 3 & $\begin{array}{l}\text { HIV can be transmitted through free sexual } \\
\text { intercourse }\end{array}$ & 202 & 99 & 2 & 1 \\
\hline 4 & $\begin{array}{l}\text { HIV transmission can occur through } \\
\text { mosquito bites }\end{array}$ & 163 & 79.9 & 41 & 20.1 \\
\hline 5 & $\begin{array}{l}\text { Simultaneous use of the bathroom can } \\
\text { transmit HIV }\end{array}$ & 127 & 62.3 & 77 & 37.7 \\
\hline 6 & $\begin{array}{l}\text { A person who has free sexual intercourse is } \\
\text { at high risk of developing HIV }\end{array}$ & 200 & 98 & 4 & 2 \\
\hline 7 & $\begin{array}{l}\text { Adolescents are strongly associated with } \\
\text { risky sexual activity and the use of drugs }\end{array}$ & 166 & 81.4 & 38 & 18.6 \\
\hline 8 & $\begin{array}{l}\text { AIDS is a collection of symptoms of immune } \\
\text { system damage disease }\end{array}$ & 180 & 88.2 & 24 & 11.8 \\
\hline 9 & $\mathrm{HIV/AIDS}$ is a curable disease & 163 & 79.9 & 41 & 20.1 \\
\hline 10 & $\begin{array}{l}\text { Adolescents are one of the groups at risk for } \\
\text { HIV/AIDS infection }\end{array}$ & 168 & 82.4 & 36 & 17.6 \\
\hline 11 & $\begin{array}{l}\text { AIDS is the same as HIV, both are terms that } \\
\text { state the same disease }\end{array}$ & 87 & 42.6 & 117 & 57.4 \\
\hline 12 & $\begin{array}{l}\text { HIV/AIDS can be transmitted through blood, } \\
\text { bodily fluids, sperm, and the vagina }\end{array}$ & 199 & 97.5 & 5 & 2.5 \\
\hline 13 & $\begin{array}{l}\text { HIV/AIDS can be caused by biological } \\
\text { factors, where infection in children can be } \\
\text { transmitted directly from the mother }\end{array}$ & 175 & 85.8 & 29 & 14.2 \\
\hline 14 & $\begin{array}{l}\text { HIV can occur through various means: } \\
\text { sexual contact, contact with blood or bodily } \\
\text { fluids, mother to child during pregnancy }\end{array}$ & 196 & 96.1 & 8 & 3.9 \\
\hline 15 & $\begin{array}{l}\text { A mother who recently has HIV/AIDS can } \\
\text { program her pregnancy }\end{array}$ & 141 & 69.1 & 63 & 30.9 \\
\hline 16 & $\begin{array}{l}\text { The transmission of HIV/AIDS may occur } \\
\text { during men and woman sexual intercourse }\end{array}$ & 189 & 92.6 & 15 & 7.4 \\
\hline
\end{tabular}
whether done in a vaginal, oral, or anal method 


\begin{tabular}{rlcccc}
\hline 17 & $\begin{array}{l}\text { For drug users utilizing syringe in an } \\
\text { alternating pattern, this pattern may expose } \\
\text { them to HIV }\end{array}$ & 190 & 93.1 & 14 & 6.9 \\
18 & $\begin{array}{l}\text { ARV (Anti Retroviral) is a drug used for } \\
\text { people with HIV / AIDS }\end{array}$ & 71.1 & 59 & 28.9 \\
19 & $\begin{array}{l}\text { HIV/AIDS cannot be transmitted through } \\
\text { shaking hands. cuddling or kissing lips }\end{array}$ & 117 & 57.4 & 87 & 42.6 \\
20 & 98 & 48 & 106 & 52 \\
\hline
\end{tabular}

Based on table 8 above, it can be seen that questions with the most correct attempt had a similar type of question that was asking about transmission from HIV /AIDS through free sex which was on question number (3), (6), and (12).

\section{Discussion}

Based on tables above, it can be seen that the majority of respondents had a good knowledge level about HIV/AIDS. This result was not in line with the research conducted by Siti et al. [9] in 2017 at SMKN 3 Mataram, from a total sample of 85 people who were grade XI senior high school students, the results obtained in the study showed that most students had less knowledge of 44 people $(51.76 \%)$ and who had good knowledge were only 5 people $(5.88 \%)$. According to Mubarak [10], education level and the surrounding environment were factors that can affect a person's level of knowledge. Based on the theory, it can be suspected that the difference in the knowledge level of this research with the research by Siti et al. [9] due to class differences, this research was conducted at grade XII high school while the research by Siti et al. [9] was conducted at grade XI high school. Besides, this research was conducted in one of the major cities and was a private school with the majority of samples were in the upper-middle class economy so that it was expected to get better results than the research by Siti et al. [9]. However, two studies conducted by Sinulingga et al. [11] in 2018 and Suhud [12] in 2013 in the same city as the researchers had in line results. In the research by Sinulingga et al. in 2018 conducted at Methodist - 1 Medan High School, out of a total of 129 respondents obtained the majority of respondents had a good knowledge level, with the number of 85 people (65.9\%), 44 people (34.1\%) had sufficient knowledge, and no one had less knowledge [11]. Research conducted by Suhud in 2013 also showed results that were not much different. With a total sample of 96 respondents who were students at the Public High School 1 Medan, it was found that the majority of respondents had a good level of knowledge of 52 people (54.2\%), a sufficient level of knowledge of 30 people (31.2\%), and a less level of knowledge of 14 people (14.6\%) [12]. The data mentioned above, shows the majority of female were at a better level of knowledge than male. However, this could not be concluded because the number of female respondents were more than male. The results of research conducted by Isnaini [13] in 2017 and Berek et al. [14] in 2018, stated that women had better HIV/AIDS knowledge compared to men. This was because women were considered to be more aware and attentive to health problems than males. Rohmah's research [15] in 2019 stated that the source of information directly affects respondent's level of knowledge. Information was 
a source of knowledge. The more information and type of information a person had can influence and increase one's knowledge [15]. In previous study conducted by Martilova [8] in 2020, it showed that respondents who obtained information from non-health workers had 3.9 times less knowledge in HIV/AIDS prevention than respondents who obtained information from health workers. According to Mubarak, a person's level of education can influence the way they view and how they convey information. The higher a person's level of education the easier it is for them to receive and convey the information they have [10]. According to research conducted by Salamah and Delfriana [16] in 2017 at Public High School 1 Hinai showed that there was a significant relationship between the level of parents last education and adolescent knowledge of sex education. While the research conducted by Siti et al. [9] in 2017 at SMKN 3 Mataram showed that the high level of parent's last education did not guarantee the level of knowledge, especially the level of knowledge about HIV / AIDS in respondents, this can be caused by parents who were busy working so that they rarely meet with respondents. Based on table 8 above, it can be seen that questions with the most correct attempt had a similar type of question that was asking about transmission from HIV /AIDS through free sex which was on question number (3), (6), and (12). The results were in line with research conducted by Wahyuni \& Sudarto [17] in 2017 and Sianipar [18] in 2019. In the study conducted by Wahyuni \& Sidarto in 2017, which analyzed secondary data of SDKI 2012 with a sample number of 41,004, that the majority of Indonesians know about HIV / AIDS transmission with a percentage of 79.68\% [17]. In line with Sianipar's research in 2018, with 258 samples from Public High School 2 Pematang Siantar, it was found that the knowledge level about HIV/AIDS transmission was mostly at a good level with a total of 134 respondents (51.9\%) [18]. Question with the least correct attempt was about the difference of terminology between HIV and AIDS, which in the questionnaire was located on number (11). These results were thought to be related to media education that tend to combine the term HIV with AIDS without providing a more complete context. The results obtained in this study were different from the results of the previous research conducted by Yani et al. [19] in 2017 and Ilham et al. [20] in 2020. From a study conducted by Yani et al. in 2017, that's conducted in one of the schools in Pangandaran with a total sample of 46 students, it was found that the majority of students already understood the difference in terminology between HIV and AIDS with a total of 36 students (76.6\%) [19]. The research conducted by Ilham et al. in 2020 with a total sample of 70 respondents who were part of the populations of one of the boarding schools in Mataram, found that the majority of respondents answered the correct question item asking about the understanding of HIV and AIDS [20].

\section{Conclusion}

From this study, it was found that the level of knowledge about HIV/AIDS was mostly in a good category. The Internet was the most widely used media as a source to find information about HIV/AIDS in this study. In the good knowledge level group, respondents received the most 
information about HIV/AIDS from the internet. In the good knowledge level group, the last education of the respondent's parents was at the highest level of S1 education. The future research was expected to submit the questionnaire directly to respondents to see a better picture of knowledge level.

\section{REFERENCES}

[1] Aru W. Sudoyo, Buku Ajar Ilmu Penyakit Dalam Jilid III, Edisi VI, Pusat Penerbitan Departemen Ilmu Penyakit Dalam Fakultas Kedokteran Universitas Indonesia, Jakarta, 2014.

[2] UNAIDS, Global HIV and AIDS statistics 2019 Fact Sheet, 2019. [Online]. Available: https://www.unaids.org/en/resources/fact-sheet [Accessed: 20 March 2020].

[3] Pettifor, A., Stoner, M., Pike, C. and Bekker, L.G., "Adolescent lives matter:preventing HIV in adolescents", Current Opinion in HIV and AIDS, vol. 13, no. 3, pp. 265. 2018.

[4] UNICEF, HIV and AIDS in Adolescent, 2019. [Online]. Available: https://data.unicef.org/topic/adolescents/hiv-aids/ [Accessed: 17 April 2020].

[5] Sudikno, S., Simanungkalit, B. and Siswanto, S., "Pengetahuan HIV dan AIDS pada remaja di Indonesia (Analisis Data Riskesdas 2010)", Jurnal Kesehatan Reproduksi, vol. 1, no. 3, pp. 145-154. 2011.

[6] Asmadi, Tingkat Pengetahuan Remaja Tentang HIV/AIDS di Desa Simpang Empat Kabupaten Asahan. Sarjana [Skripsi]. Medan, Fakultas Keperawatan USU, 2014. [Online]. Available: http://repository.usu.ac.id/handle/123456789/40500.

[7] Ratyas Ekartika Puspita C. E., Faktor-Faktor yang Mempengaruhi Perilaku Remaja Tentang Pencegahan HIV/AIDS di SMA Negeri 2 Sleman Tahun 2018. Sarjana [Skripsi]. Yogyakarta, Poltekkes Kemenkes Yogyakarta, 2018. [Online]. Available: http://eprints.poltekkesjogja.ac.id/1458/1/SKRIPSI\%20RATYAS\%20EKARTIKA\%20PC N.pdf.

[8] Martilova, Dona, "Faktor yang Mempengaruhi Pengetahuan Remaja Dalam Pencegahan HIV AIDS di SMA N 7 Kota Pekanbaru", JOMIS (Journal of Midwifery Science), vol. 4, no. 1, pp. 63-68. 2020.

[9] Siti WD, Catur Pamungkas, dan Rizkia Amilia, "Gambaran Tingkat Pengetahuan Remaja Tentang HIV/AIDS di SMKN 3 Mataram", Midwifery Journal: Jurnal Kebidanan UM. Mataram, vol. 2, no. 2, pp. 24-26, 2017.

[10] Mubarak, Wahit Iqbal et al., Promosi Kesehatan untuk Kebidanan, Salemba Medika, Jakarta, 2011.

[11] Sinulingga, AG, Burhan, dan Rodiah Rahmawaty Lubis, "Tingkat Pengetahuan HIV/AIDS dan Sikap Remaja Terhadap Hubungan Seksual Pranikah Siswa-Siswi Kelas XI IPA NonUnggulan Tahun Ajaran 2016/2017 di SMA Methodist-1 Medan”, Jurnal Kedokteran Methodist, vol. 11, no. 2, pp. 284-292. 2018.

[12] Suhud, R.F., Gambaran Pengetahuan dan Sikap Remaja Tentang HIV/AIDS di SMA Negeri 1 Medan Tahun 2013. Sarjana [Skripsi]. Medan, Universitas Sumatera Utara, 2013. [Online]. Available: https://repository.usu.ac.id/ handle/123456789/41581.

[13] Isnaini, Nurul, "Pengetahuan Siswa SLTA Tentang HIV/AIDS di Sekolah Menengah Tingkat Atas (SMA) Gajah Mada Bandar Lampung Tahun 2017”, Jurnal Kesehatan Holistik (The Journal of Holistic Healthcare, vol. 2, no. 4, pp. 223-228. 2017.

[14] Berek, P. A. L., Maria Florida B.E., Yusfina M. R., Christina Anugrahini, Hubungan Jenis Kelamin dan Umur dengan Tingkat Pengetahuan Remaja Tentang HIV/AIDS di SMAN 3 Atambua Nusa Tenggara Timur. Sarjana [Skripsi]. NTT, Program Studi Keperawatan Universitas $2018 . \quad$ Timor, 2 Anline]. https://jurnal.unimor.ac.id/JSK/article/download/85/34/

[15] Rohmah, S., "Pengaruh Dukungan Teman Sebaya, Sumber Informasi, dan Pengetahuan Terhadap Perilaku Pencegahan HIV/AIDS di Kalangan Pelajar SMKN Kalinyamatan Jepara Tahun 2016", Journal of Midwifery And Public Health, vol. 1, no. 2. 2019.

[16] Salamah, Siti dan Delfriana Ayu A., "Pendidikan Orang Tua dengan Pengetahuan Remaja Tentang Pendidikan Seks", JUMANTIK, vol. 3, no. 1, pp. 109-114. 2017.

[17] Wahyuni, A. Sri dan Sudarto Ronoatmodjo, "Hubungan Antara Pengetahuan HIV/AIDS dengan Sikap Penolakan Terhadap Orang Dengan HIV/AIDS (ODHA) pada Masyarakat 
Indonesia (Analisis Lanjut Survei Demografi Dan Kesehatan Indonesia 2012)”, Jurnal Kesehatan Reproduksi, vol. 8, no. 1, pp. 41-52. 2017.

[18] Sianipar, Kandace, "Analisis Hubungan Pengetahuan Penularan dan Pencegahan HIV/AIDS Dengan Sikap Terhadap Perilaku Seksual Siswa SMAN 2 Pematangsiantar Tahun 2018", Jurnal Health Reproductive, vol. 4, no. 1, pp. 1-10. 2019.

[19] Yani, Desy Indra, Neti Juniarti, dan Mamat Lukman, "Gambaran Pengetahuan dan Sikap Tentang HIV/AIDS pada Remaja di Pangandaran”, Jurnal Pengabdian Kepada Masyarakat, vol. 1, no. 1, pp. 1-5. 2017.

[20] Ilham, Lalu Fahril, Yunita Hapsari, dan Lenny Herlina, "Hubungan Pengetahuan Tentang Infeksi HIV Terhadap Perilaku Pencegahan HIV Pranikah pada Santri SMA Sederajat di Pondok Pesantren Abu Hurairah Mataram”, Jurnal Kedokteran 2020, vol. 9, no. 1, pp. $27-$ 36. 2020. 